\title{
Si no es igualitario, no es sostenible. El turismo y los discursos para la igualdad entre mujeres y hombres
}

\author{
Margarita Sánchez Romero | Dpto. de Prehistoria y Arqueología, Universidad de Granada
}

URL de la contribución <www.iaph.es/revistaph/index.php/revistaph/article/view/3714>

Las relaciones que han mantenido a lo largo de la Historia mujeres y hombres se definen por el desigual ejercicio del poder. Esto no quiere decir que no haya habido mujeres poderosas o influyentes, sino que el patriarcado ha considerado estos casos como excepcionales o anecdóticos y que la norma ha sido que los hombres detenten el poder.

Para seguir manteniendo esas formas y para que nadie, sobre todo las mujeres, se rebele contra el sistema establecido se han utilizado diversas estrategias; una de ellas tiene que ver con cómo se produce el discurso histórico, un relato escrito casi exclusivamente por hombres del que se ha excluido intencionadamente a las mujeres. Ellas nunca han sido observadas como promotoras de cambios sociales o económicos; no se les atribuye el uso de tecnología; y, en la mayor parte de las ocasiones, no se las considera como productoras. En definitiva, ni las mujeres, ni sus acciones, ni sus prácticas contribuyen a explicar quiénes somos. Así, no sólo se anula a las mujeres sino que, además, tanto ellas como sus trabajos y experiencias se sitúan en los márgenes de las narrativas históricas y, por tanto, fuera de la memoria colectiva.

Como los discursos científicos que se han escrito sobre los grupos humanos del pasado casi nunca han prestado atención a las mujeres, estas no aparecen en los textos divulgativos más allá de los estereotipos que se han construido sobre ellas: bien la mujer exuberante y sexualmente receptiva; bien la mujer madre guiada en sus acciones únicamente por el instinto biológico de cuidar. Un simple recorrido por libros de texto, revistas de divulgación científica, imágenes en medios de comunicación e incluso exposiciones (permanentes o temporales) en museos nos situarán a las mujeres en uno de estos dos lugares o en la más absoluta invisibilidad.
A este hecho habría que sumar que, al construir el concepto de patrimonio histórico, las experiencias de las mujeres como creadoras, promotoras, estudiosas o usuarias han sido escasamente atendidas no sólo por la consideración de los distintos tipos de patrimonio existentes (que sólo muy recientemente ha empezado a diversificarse), sino también por la idea de la autoría del genio creador como base del mismo. Ambos hechos desligan a las mujeres de una genealogía creadora femenina.

Y esto no es en absoluto banal; las mujeres, las niñas que no se ven reflejadas, o lo hacen de manera estereotipada, en museos, exposiciones temporales, centros de visitantes y en sus textos divulgativos, entienden que no forman parte de los hechos que han ido componiendo

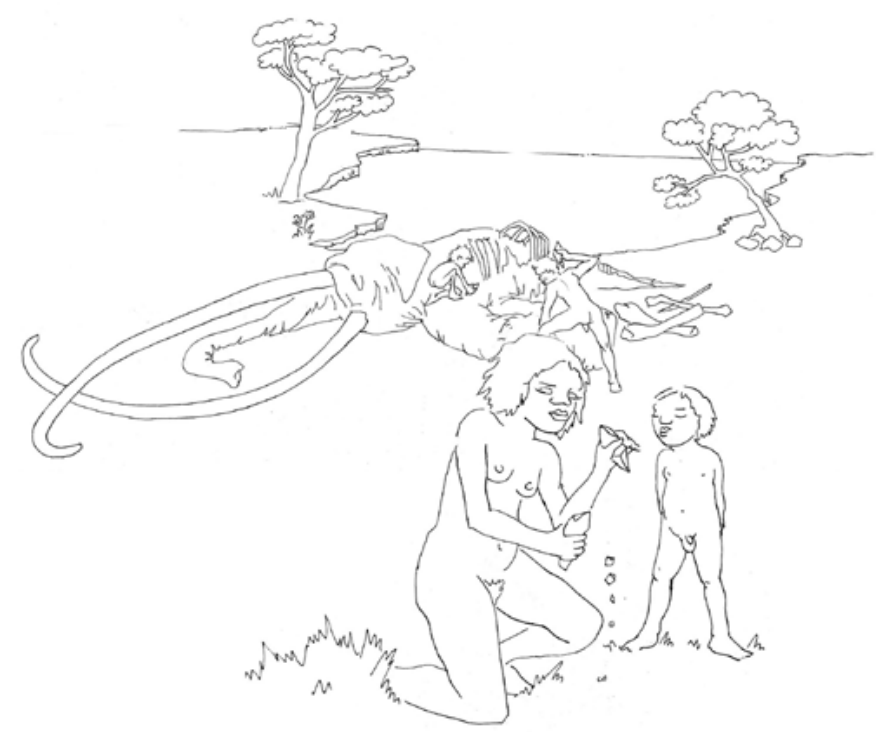

Recreación de una escena de fabricación de útiles de piedra y actividad de carroñeo en la Cuenca de Orce | dibujo Carmen Merino Rodríguez (SÁNCHEZ ROMERO, 2012) 
nuestra historia o que lo han hecho sólo de manera restringida. Ellas no protagonizan las escenas de las reconstrucciones "ideales"; se ven invisibilizadas por un lenguaje pretendidamente "neutro"; la explicación que se les da en los recorridos prioriza actividades que hemos entendido como exclusivamente masculinas. Esto irremisiblemente las relega a posiciones de desigualdad antes los hombres a la hora de explicar cómo hemos llegado a ser lo que somos, lo que no sólo es falso, sino que además es injusto, porque las mujeres siempre han estado en el centro de la vida social de cualquier comunidad. Mediante estas prácticas convertimos el objeto y el sujeto del patrimonio histórico en un individuo adulto masculino y heterosexual, modelo que se subvierte en muy pocas ocasiones.

Deberíamos tener en cuenta que la historia, la arqueología o la historia del arte constituyen algunas de las formas de construir discursos más directamente relacionadas con la identidad del grupo social; generan referentes comunes que son recordados, reiterados y compartidos por todo la comunidad. El patrimonio se convierte en una representación simbólica de la identidad, en un factor de cohesión, en un espacio referencial. En un poderosísimo instrumento de transformación social que tiene (o al menos debería tener) en los usos turísticos, uno de los mejores aliados para transmitir esas nuevas formas de transmitir el conocimiento sobre quiénes somos.

Nos preocupa que el turismo sea sostenible medioambientalmente, pero debería movernos también que fuese socialmente responsable; que la información que se proporciona al visitante considerase todas las variables o propusiera otras alternativas y para eso hemos de generar conocimiento de calidad mediante una investigación de excelencia.

Es cierto que en los últimos años se está generando una amplia literatura científica relacionada con las mujeres, el género o la teoría queer y las nuevas formas de musealización y difusión del patrimonio. Y también es cierto que existe una legislación absolutamente clara y contundente en este ámbito. Pero la realidad es que todo esto tiene escaso o nulo reflejo en los museos, en los centros de recepción de visitantes de los conjuntos arqueológicos y monumentales, en exhibiciones permanentes o exposiciones temporales. Queda, en la mayor parte de las ocasiones, en manos de la buena voluntad y el compromiso de las personas que gestionan estos espacios. $Y$ todo ello, a pesar de que la capacidad explicativa de las instituciones que trabajan con el patrimonio histórico en nuestro país las convierten en muy potentes herramientas de deconstrucción de estereotipos sobre las mujeres, sobre los hombres y sobre las relaciones que mantienen entre ellos. Es indispensable seguir apostando por actividades que potencien la igualdad y que den el valor que les corresponde a las mujeres de nuestro pasado. Es necesario asumir la perspectiva de género en las tareas de difusión del patrimonio histórico, de forma que se incluya en los materiales didácticos y en los discursos explicativos de museos y conjuntos arqueológicos y monumentales; que la experiencia de calidad a la que tanto se alude desde las instituciones patrimoniales y turísticas incluya una explicación histórica que considere la variabilidad de los actores y actrices, independientemente de su sexo, género, edad, estatus social o creencias. 
a debate Patrimonio, turismo y género. Estrategias para integrar la perspectiva de género en el patrimonio histórico | coordinan Margarita M. Birriel Salcedo, Carmen Rísquez Cuenca

\section{BIBLIOGRAFÍA}

- GONZÁLEZ MARCÉN, P. (2008) La otra prehistoria: creación de imágenes en la literatura científica y divulgativa. Arenal, 15:2, pp. 91-109

- QUEROL, M. A. (2014) Museos y Mujeres: la desigualdad en Arqueología. Arqueoweb, 15, pp. 270-280

- QUEROL, M. A.; HORNOS, F. (2011) La representación de las mujeres en los modernos museos arqueológicos: estudio de cinco casos. Revista Atlántica-Mediterránea de Prehistoria y Arqueología Social, 13, pp. 135-156

- SÁNCHEZ ROMERO, M. (2012) Las mujeres en las sociedades prehistóricas del altiplano granadino. En BIRRIEL SALCEDO, M; ROBLES VIZCAÍNO, S. (coord.) Las mujeres en la historia: itinerarios por la Provincia de Granada. Granada: Universidad de Granada, 2012, pp. 14-43

- SÁNCHEZ ROMERO, M. (2014) El patrimonio prehistórico y la construcción de discursos igualitarios sobre nuestro pasado. ICOM-CE digital, 9, pp. 28-35

- SÁNCHEZ ROMERO, M. (2015) (Pre)Historia de las mujeres: reflexiones sobre la Arqueología como estrategia para la equidad. Discurso de ingreso en la Real Academia de Nobles Artes de Antequera. Exlibris 